\title{
EVALUATION OF EDUCATION AND TRAINING PROGRAM FOR CIVIL SERVANTS: A NEW APPROACH TO IMPROVING EMPLOYEE PRODUCTIVITY
}

\author{
Deden Komar Priatna \\ Winaya Mukti University. Bandung. Indonesia. \\ Email: dedenkomar@yahoo.com
}

\begin{abstract}
The purpose of this study was to determine the magnitude of the influence of the implementation of existing education and training programs on the work productivity of civil servants. Based on the results of data processing, it is known that the elements of implementing education and training programs that must be considered and improved are as follows: Training Materials, Non-Formal Education, Training Schedule, Instructor Hospitality, Training Variations, Training Methods, and Training Manuals. While the elements of the education and training program organizers that must be maintained are as follows: Formal Education, Instructor Skills, Instructor Capabilities, Training Facilities, Training Curriculum, Training Evaluation. The implementation of the education and training program has an effect on the work productivity of civil servants and the effect of the implementation of the education and training program is more dominant, this is because the implementation of the education and training program is more frequent and more applicable even though it still seems theoretical in the work of civil servants. Therefore, the right education and training program will have an impact on increasing the productivity of its employees.
\end{abstract}

Keywords: Performance Evaluation; Training; Productivity

\section{EVALUASI DARI PROGRAM PENDIDIKAN DAN PELATIHAN PNS : BERBASIS PENDEKATAN BARU UNTUK MENINGKATKAN PRODUKTIVITAS PEGAWAI}

\begin{abstract}
ABSTRAK. Tujuan penelitian ini adalah untuk mengetahui pengaruh pelaksanaan program pendidikan dan pelatihan yang ada terhadap produktivitas kerja PNS. Berdasarkan hasil pengolahan data, maka diketahui unsur-unsur pelaksanaan program pendidikan dan pelatihan yang harus diperhatikan dan diperbaiki adalah sebagai berikut : Materi Pelatihan, Pendidikan Non Formal, Jadwal Pelatihan, Keramahan Instruktur, Variasi Pelatihan, Metode Pelatihan, dan Buku Pedoman Pelatihan. Sedangkan unsur-unsur pelaksanaan program pendidikan dan pelatihan yang harus dipertahankan, adalah sebagai berikut: Pendidikan Formal, Keahlian Instruktur, Kemampuan Instruktur, Sarana Prasarana Pelatihan, Kurikulum Pelatihan, Evaluasi Pelatihan. Pelaksanaan program pendidikan dan pelatihan berpengaruh terhadap produktivitas kerja PNS dan pengaruh pelaksanaan program pelatihan lebih dominan, hal ini demikian karena pelaksanaan program pelatihan lebih sering dilakukan dan lebih aplikatif walaupun masih terkesan teoritis pada pekerjaan PNS. Karena itu program pendidikan dan pelatihan yang tepat akan memberikan dampak pada peningkatan produktivitas pegawainya.
\end{abstract}

Kata Kunci: Evaluasi Kinerja; Pelatihan; Produktivitas.

\section{INTRODUCTION}

The ability of an organization to evaluate and assess the performance of executives in the public sector is essential if the performance management system is realistically expected to drive the successful implementation of the organization's strategic goals and objectives. In this paper we provide a model that can be used to evaluate executive performance in government organizations (Siswantini,.., Ayuni, \& Mulyana, 2014).

This model allows executives to focus on what is important to the organization and their customers, and relates their performance evaluation not only to organizational goals, but to the importance of each goal; thus providing leaders an open and explicit relationship between individual performance attributes and organizational goals (Hanaysha \& Tahir, 2016).

We measure an individual's level of achievement by defining attributes or performance measures and then incorporating them into higher-level goals. We then show how to use models to rank performance among executives and we discuss what rankings mean, how they can be used to assess performance and the limitations of using models for performance evaluation (Limakrisna, Noor, \& Ali, 2016).

A large number of public service organizations in the UK have introduced performance monitoring systems *. In doing so, attention tends to focus on suitability and on appropriate measures and performance indicators. A large number of indicators have been published and a lot of ink has been used to evaluate heuristic values. What performance picture does this indicator show?

The performance monitoring system has a hidden dimension that is important below the waterline of indicators and actions. This includes the basis and logical values on which the entire system is based. Weaknesses in this area, together with a lack of respect for the distinct values lurking in performance monitoring systems, result in severe implementation problems. The performance monitoring system design reflects a specific picture of public administration (Platis, Reklitis, \& Zimeras, 2015). These range from new public sector management, with 
an emphasis on technical developments in public policy analysis, market-oriented metaphors and an emphasis on operational efficiency and effectiveness, to those whose image choices focus on the importance of community values and public services (Siswantini et al. ., 2014).

Implementation problems arise when these images conflict in public service organizations or when organizational stakeholders have a significantly different image from the ruling organizational elite. The introduction of a performance monitoring system can raise important issues in change management (Handayani Sri, Fariyanti Anna, 2016). Performance criteria are by definition full of value. Therefore, they are the currency of political debate. When considering the performance evaluation of public service organizations, we need to go beyond just a discussion of the data used for the development of performance indicators.

Performance evaluation in public service organizations is full of theoretical, methodological and practical issues that arise in any discussion of democracy. Some of these problems are discussed in this article (Herawati \& Prayekti, 2017).

Changes in communication / information require Human Resources (HR) to play a more optimal role in an organization. In this connection, globalization cannot be avoided in HR performance. In other words, companies or organizations that want to go with the flow must be able to prepare themselves in the arena of global business competition (Abrantes Ferreira, Gonçalves Avila, \& Dias de Faria, 2010).

One of the companies engaged in the export quality processing industry will be marketed one of them to Japan, which is a country that is very consistent with quality. Currently, civil servants in Indonesia show a decrease in work productivity (Sutanto \& Kurniawan, 2016).

Based on the description of the problem above, if the development of civil servant knowledge, especially the education and training program is not effective and efficient, which is not carried out by "the right job and the right man", then work productivity will decrease, if this condition is allowed to continue, it is possible the company will experience a lot of losses, therefore it is necessary to evaluate the performance of the civil servant education and training program by using an analysis of interest and performance, and measuring its effect on the work productivity of civil servants in Indonesia so that this research is expected to become material for evaluation and input for regional and central governments, especially for Human resources, especially for improving the existing science development system, especially the education and training program (Priatna \& Roswinna, 2019.

The globalization of the world economy and the national economic crisis for companies engaged in export products are quite a challenge so that the preparation and support of government policies related to export-import will be one of the forces to penetrate the global market (Goerzen, Asmussen, \& Nielsen, 2014).

In general, company resources consist of tangible assets, intangible assets, and organizational capabilities (Hanaysha \& Tahir, 2016). Not all company resources are the company's core capabilities. Resources can be categorized as core capabilities if they meet the criteria of value, scarcity, cannot be completely replicated and cannot be replaced, and can be managed (Matanda \& Ewing, 2012).

The role of human resources in a company is very important in improving company performance because the HR element in a company is very important. However, the ability and motivation of primary schools is very much needed for the progress of the company itself, so education and training programs need to be considered to develop the abilities and motivation of these human resources (Priatna \& Roswinna, 2019).

This is according to Bernardin's opinion, namely the allocation, assessment and evaluation of human resources including education and training \& development (Diklat). Thus, from the opinion of experts, it can be concluded that education and training programs are very important for companies to pay attention to (Bailey, Albassami, \& AlMeshal, 2016).

To find out whether an individual feels satisfied or dissatisfied in a certain situation, four theories are usually used, namely fulfillment theory (fulfillment theory), reward theory (reward theory), gap theory (difference theory), and justice theory (equity theory) and individual theory. This satisfaction will create work productivity (Platis et al., 2015).

The assessment management important instrument for measuring employee performance, explained individual decisions, as demotion or promotion, retention and help to develop the ability of them through provide feedback or training. hal is also contributes to advance supervisor-employee understanding and strengthen the organization. (Kurtessis et al , 2015) Besides it, The assessment effective believed to motivate employees tried to improve the assessment by linking in return for that relies on performance (Siengthai, Sukirno, 2011).

Although it was organization that large enough agreement can give benefits from using performance assessment, in practice the term, the theory benefits appear to remain unfulfilled in some kasus.beberapa studies other stated that trustees and employees do not support the field of using (Zagenczyk, Scott, Gibney, Murrell and Thatcher, 2010 ). Especialy in, Public sector observation anekdotal mere and survey the findings show that component extrinsic embedded in the performance of assessment can cause a crowding out effect on employees motivation, resulting in feeling stress, demotivation, or even burnout (Dyer, Gregersen, \& Christensen, 2008).

In addition, further proof had a reduce in belief in the effectiveness, integrity and justice from the performance 
of an aarssen public, (Lw \& Crimi, 1, 2016) leisure time and the work hard play loudly hypothesis, journal of psychology et al, 2018) for excample, (Kurtessis et al, 2015) describing the usual negative attitude toward performance of a judgment in between federal employees.

In the survey, some employees expressed concern that their performance judged not enough, while some supervisor-level provide feedback on employee performance considered contrary to duty of another and therefore jobs not menyenangkan. Besides it, most workers in the survey also believe there is a quota system for performance assessment, Tuma, and Pratt, (1982). Training in clinical psychology: children. The survey ldots Clinical \& Psychology Teenager.

Several studies have begun to emphasize a member of the organization access to business performance measurement (both supervisors and subordinate) it is very important to overall success in performance management and effectiveness of, because of how they affect their behavior (Sagita, Susilo, \& Cahyo, 2018). This happened because, like (Nalbesleben \& Wheeler, 2008) noted, about the notion of equality and acceptance of the order of this system then function not only of the system itself but also from organizations and individual characteristics. Especialy he suggested that some of the characteristics of individuals and organizations, individual employees feedback-seeking behavior and participatory style of management contribute increasing revenue from membership. performance assessment.

He emphasizes that when the need for feedback having the power is the great, and managers are willing to involve employees in decision-making process of, acceptance judgment performance in between incumbents (Aarssen, will be higher lw, \& Crimi 1 2016). Free time, and hard at work - play hard hypothesis. Open psychology journal. et al, 2018), Other words Even though we may be able to design a system performance assessment which is technically sound and accurate, without acceptance judgment, employee performance the quality and success as a whole was compromised (Aarssen, Lw \& Crimi 1, 2016, legacy Free time, and ' hard at work - play hard hypothesis, Open psychology journal. et al, 2018).

Others also shows that the reason employees manager or refusal performance evaluation of should be identified and reduced to maximize assessment effectiveness the performance of (Mathew, Rv, \& Panchanatham, N. 2016, study exploration women development: cases entrepreneurship india .journal of research in marketing and entrepreneurship, et al, 2003) strong a statement also large enough, employees reaction to performance measurement is one factor ignored that may be closely related most important things in evaluate the success of a system rank.

Remember this (Kurtessis et al 2015) performance assessment of the opinion that the acceptance by members of the organization is a function of the process and hasil. proses refers to the extent to which employees the view that assess performance reflect their actual performance or other contributions to the organization they, and also the extent to which employees understand their superior to make decisions based on information obtained from scoring, kinerja.dengan other words that is all about whether employees believe the process of this evaluation is applicable or fair.

The result of performance assessment than workers's perspective is a fair acclaim or reward knight performance that an organization they work for, and motivation to improve their performance (Morgan, Richey Jr, \& Autry, 2016). No need to ask if there was a payment system services or tidak.hal is more about whether employees's good performance recognized by an agent or by supervisor with other words. Perception of justice and equity make performance and employee performance assessment see as valid and take to fix (Siahaan performance and work performance, work \& Lumbanraja; 2016).

Tuma, and Pratt, (1982). Training and clinical training of child psychology: clinical survei. Psychology teenager, also proposed. Employee performance assessment determined by the extent to which employees view that their performance was considered fairly and have in return for using the concept of distributive justice. And procedural proseduralkeadilan assessment is based on performance and was considered fair, legitimate distributive justice while referring to whether the reward for good performance is just (Kurtessis et al, 2015).

Koubova \& Buchko, 2013 noted "the essence receive a judgment of employee performance is whether a system used is procedurally fair and are valid for employees" recipients repeat of this article, after said definition (Masakure, 2016), the performance assessment is defined as perception and justice procedural of employee a distribution of related with the evaluation process performance bagian next this report proposed the main factors organization that helped drive revenue employees performance the assessment system of using many lens theoretical.

Based on the theoretical description above, the civil servant guidance policy, in this case the training program, has an effect on the work productivity of civil servants. (Hakim \& Hadipapo, 2015), examined that industries involved in the manufacturing industry are more suitable to use work productivity measurements based on "standard direct working hours with actual direct working hours".

From some of the theories described above, the theory described by Flippo about an effective method for developing civil servants is through education and training which can increase the level of productivity of human resources. Finally, it can be concluded from the existing framework as a basis for modeling as below. The research paradigm is as follows:

\section{METHOD}




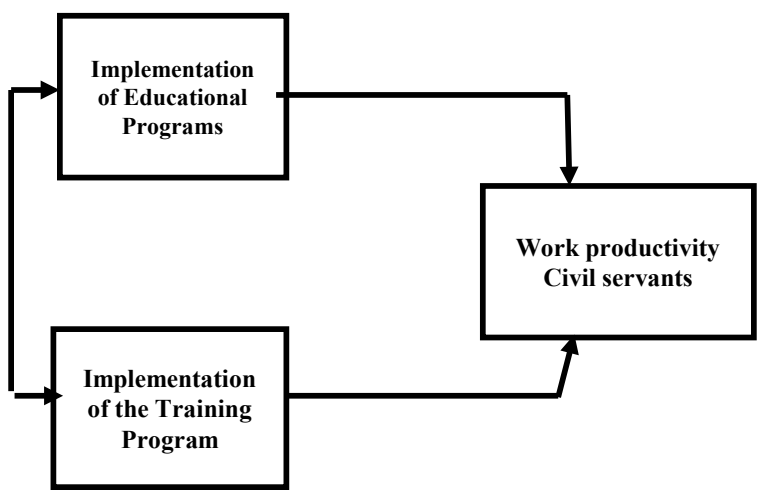

Figure 1. Model Conceptual

Given the research objectives, verification this research is descriptive penelitian is research aimed at get a description of characteristics of the variable sifat research may try verification the truth of a hypothesis by gathering data in the field in this research which will do program implementation the education and training has an effect on labor productivity? Given the trait of this research is done through and verification descriptive data collection in the field, research is descriptive methods used method of surveying survey methods and clear. The kind of research used is correlational, a kind of study to show that there was an association between the independent variable, in this case in the training program in the dependent variable, the productivity kerja. Unit of analysis of an individual in this study, which means that he uses observation unit state civil servants in Indonesia.

Judging from the time horizon, this research is cross action, namely information from part of the population (sample of respondents) is collected directly on the scene empirically, to find out the opinion of several populations on the object under study, as stated by (August 2012) et al., 1997).

In this study, the sample size is determined by the form of statistical test to be used. The statistical test used is path analysis, where the path coefficient is the correlation coefficient. Thus the minimum sample size for this pathway analysis can be determined through the formula for the minimum sample size for the correlation coefficient which is carried out iteratively (repeated calculations).

By pencepreliminary listen to obtain parameters $\rho$ where research on the same topic has never been done, it was obtained $\rho$ (smallest correlation coefficient $)=0.653$. So with $=0.653 \alpha=0.05$ and $\beta=0.10$, a minimum sample size of (n) of 199 is obtained.

Sampling from each population stratum in this study used the stratified random sampling method where each member of the population has the same opportunity to be selected as the sample. The population in this study are civil servants in Indonesia whose representatives are taken in the Provincial and Municipal Governments throughout Indonesia by means of quota sampling.

To answer the problem formulation, path analytical method is used, because it wants to test the causal relationship between variables. The analysis of the implementation of the training program as the independent variable and work productivity as the dependent variable. From the results of interviews with 999 civil servants in Indonesia who became respondents, as well as testing the effect of the hypothesis between the implementation of the training program and the work productivity of employees. The causal relationship between sub variables can be described in the form of a diagram as follows:

Information :

$$
\begin{array}{ll}
\mathrm{X} 1 & =\text { Implementation of Educational Programs } \\
\mathrm{X} 2 & =\text { Implementation of Training Programs } \\
\mathrm{Y} & =\text { work productivity }
\end{array}
$$

Before concluding the causal relationships that have been described in the path diagram, the significance of each path coefficient has been calculated. To test the path coefficient can be reached in two ways, namely as a whole (overall) and individually.

1. Overall Testing (overall)

The hypothesis of this overall test is:

Ho: $\mathrm{pYx} 1=\mathrm{pYx} 2=\mathrm{pYx} 3=\ldots=\mathrm{pYxk}=\mathrm{o}$

$\mathrm{H} 1$ : At least there is a $\mathrm{PYxi} \neq 0$

With F-snedecor test statistics:

$\mathrm{F}=$ With free degrees $\mathrm{v} 1=\mathrm{k}$ and $\mathrm{v} 2=\mathrm{nk}-1$

\section{Individual Testing}

If the overall test Ho is rejected, it means at least lack there is a PYxi $\neq 0$. To find out which pYxi is equal to zero,

or to test the proposed conceptual hypothesis, testing is carried out individually.

The statistical hypothesis to be tested:

a. Ho: $\mathrm{pYxi}=0$ against $\mathrm{H} 1: \mathrm{pY} \mathrm{xi} \neq 0$

b. Ho: $\mathrm{pYxi} \leq 0$ against $\mathrm{H} 1: \mathrm{pYxi}>0$

c. Ho: $\mathrm{pYxi} \geq 0$ against $\mathrm{H} 1: \mathrm{pYxi}<0$

Test formula

$$
\mathrm{I}=1.2 \ldots
$$

The test statistic above follows the $\mathrm{t}$ distribution with degrees of freedom nk-1.

\section{RESULT AND DISCUSSION}

\section{Effect of Implementation of education and training programs on Work Productivity.}

Discussion of the results of this study includes analyzing the implementation of education and training programs, on the work productivity of civil servants as the dependent variable, the results of interviews with as many as 999 civil servants who were used as respondents. The causal relationship between these variables can be described in the form of a diagram as follows:

$\mathrm{X} 1$ = Implementation of Educational Programs

$\mathrm{X} 2$ = Implementation of Training Programs 
$\mathrm{Y}=$ Work Productivity

$\mathrm{E}=$ Other factors that affect the productivity of civil servant work.

Next will be tested the significance of the correlation coefficient between variables X1 to X2 with the following hypothesis:

Ho $: \rho_{\text {xixj }}=0$

$\mathrm{H} 1: \rho_{\mathrm{xixj}} \neq 0$

With test statistics as follows:

then the correlation coefficient and testing are displayed in the table 1 below:

From the results of the calculation of the correlation coefficient above it turns out that the correlation Coefficient

Table 1. Correlation Between Independent Variabels

\begin{tabular}{ccccl}
\hline Coefficient & Correlation & T-test & Sig. & Conclusion \\
\hline $\operatorname{rx} 1 \times 2$ & 0.439 & 2,136 & $\begin{array}{l}0,000 \\
<0.05\end{array}$ & $\begin{array}{l}\text { Ho Rejected } \\
\text { There is a } \\
\text { significant } \\
\end{array}$ \\
& & & & relationship \\
\hline
\end{tabular}

is significant, so the calculation can proceed. The path coefficient is determined through the formulation:

PYxi $=\mathrm{i}=1,2 \ldots 7$

And the overall effect of X1 and X2 $=0.626$ While the path coefficients of other variables outside the variables $\mathrm{X} 1$ and $\mathrm{X} 2$ are determined through:

$\mathrm{pY} 1_{\varepsilon 1}=0.777$

This means that the variable implementation of education and training programs affects work productivity by $39.56 \%$ and the remaining $60.37 \%$ is influenced by other factors not included in the study.

Based on the theoretical framework that there is an influence between the implementation of education and training programs on work productivity, it will then test the overall hypothesis in the following form:

Ho $: \mathrm{p}_{\mathrm{Yx} 1}=\mathrm{pYx} 2=0$

$\mathrm{H} 1$ : Sekuthere is at least a $\mathrm{PYxi} \neq 0$

Test statistics used : $F=20,446$

With sig. level based on analysis with SPSS software obtained:

Sig. $=0,000$ less than 0.005 , then Ho is rejected, meaning it can be continued on individual testing with the following hypothesis:

Ho: $\mathrm{p}_{\mathrm{Yxi}} \leq 0$

H1 : $\mathrm{p}_{\mathrm{Yxi}}>0$

And the test statistics used are:

$$
\mathrm{i}=1,2,3
$$

Then obtained the path coefficient along with testing as follows Table 2:

The complete structural causal between the variables $\mathrm{X} 1, \ldots \mathrm{X} 7$ and $\mathrm{Y}$ can be expressed in the figure 1 above.
Table 2. Hyphoteses Testing

\begin{tabular}{|c|c|c|c|c|}
\hline Coefficient & Pathway & T-test & Sig. & Conclusion \\
\hline ryx1 & 0.228 & 1,941 & $\begin{array}{l}0.045 \\
<0.05\end{array}$ & $\begin{array}{l}\text { Ho Rejected There } \\
\text { is a significant } \\
\text { relationship }\end{array}$ \\
\hline ryx2 & 0.338 & 3,794 & $\begin{array}{l}0,000 \\
<0.05\end{array}$ & $\begin{array}{l}\text { Ho Rejected There } \\
\text { is a significant } \\
\text { relationship }\end{array}$ \\
\hline
\end{tabular}

Based on Figure 1 above, the implementation of the education and training program has an effect on work productivity, and the most dominant influence is the implementation of the education and training program, this is because the implementation of the education and training program is more frequent and more applicable even though it still seems theoretical about the work of civil servants.

The results of this study are in line with Bernardin's research, namely the allocation of human resources, assessment and evaluation including education and training $\&$ development (Diklat). Thus from the opinion of experts it can be concluded that education and training programs are very important for companies to pay attention to.

To find out whether an individual feels satisfied or dissatisfied in a certain situation, four theories are usually used, namely fulfillment theory (fulfillment theory), reward theory (reward theory), gap theory (difference theory), and justice theory (equity theory) and individual theory. This satisfaction will create work productivity (Singh, 2013; Sutanto \& Kurniawan, 2016).

Then (Sagita et al. 2018) in addition, performance performance assessment and effective believed to motivate employees to seek improved performance by connecting with performance dependent give attach although assessment that organizations large enough to provide the advantages of using performance assessment, in practice the term, the benefits appear to remain unfulfilled in some other studies said kasus.beberapa a not nor employees supporting its use, (Mathew Rv, \& Panchanatham, the development of female entrepreneurs .2016). Eksploration study: India. Kasusjournal of research in marketing and entrepreneurship et al . 2003).

The results of this study were also reinforced by (Noor \& Limakrisna, 2019) explaining the usual negative attitudes towards performance appraisal among federal employees. In the survey, some employees expressed concern that their performance was not judged fairly, while some supervisor-level employees viewed providing performance feedback as conflicting with other duties and therefore unpleasant work.

And these results are supported by (Gan \& Yu, 2015) that makes things, attitude to equality and acceptance of the ranking system is a function not only of the system itself but the group and individual characteristics, Especialy he suggests that among individuals and organizations, the 
characteristics of individual employees feedback-seeking behavior and participatory management style contribute an increase in membership income penilaian.fauzi bowo performance is emphasized that when an employee ' $\mathrm{s}$ needs for feedback is strong, and manager is willing to involve employees in decision making processes, the reception of the performance of the assessment in between incumbents is greater (Chen \& Silverthorne, 2005; Eisenberger \& Stinglhamber, 2011; Siahaan et al. , 2016).

\section{CONCLUSION}

The results of this study are in line with Bernardin's research, namely the allocation of human resources, assessment and evaluation including education and training $\&$ development (Diklat). Thus from the opinion of experts it can be concluded that education and training programs are very important for companies to pay attention to.

The implementation of the education and training program has an effect on the work productivity of civil servants and the effect of the implementation of the education and training program is more dominant, this is because the implementation of the education and training program is more frequent and more applicable even though it still seems theoretical. civil servant jobs. Therefore, the right education and training program will have an impact on increasing the productivity of civil servants.

\section{REFERENCES}

Aarssen, L. W., \& Crimi, L. (2016). Legacy, leisure, and the 'work hard - play hard' hypothesis. The Open Psychology Journal, 9. (1):7-24 DOI: 10.2174/1874350101609010007

Abrantes Ferreira, D., Gonçalves Avila, M., \& Dias de Faria, M. (2010). Corporate social responsibility and consumer perceptions of prices. Journal of Social Responsibility, 6 (2), 208-221. DOI:. org/10.1108/17471111011051720

Bailey, A. A., Albassami, F., \& Al-Meshal, S. (2016). The role of employee job satisfaction and organizational commitment in the identification of employees of the bank's internal marketing. International Journal of Bank Marketing, 34 (6), 821-840. https://doi.org/10.1108/IJBM-06-20150097

Chen, J.C., \& Silverthorne, C. (2005). Leadership effectiveness, leadership style and employee readiness. Journal of Leadership and Organizational Development. 26, (4), 280-288. https://doi.org/10.1108/01437730510600652

Dyer, J. H., Gregersen, H. B., \& Christensen, C. (2008). Entrepreneur behavior, recognition of opportunities and the origin of innovative ventures. Journal of
Strategic Entrepreneurship. 2, (4), 317-338 https:// doi.org/10.1002/sej.59

Eisenberger, R. \& Stinglhamber, F. (2011). Perceived organizational support: Fostering enthusiastic and productive employees, (pp. 187-210). Washington, DC, US: American Psychological Association, viii, 304 pp. https://psycnet.apa.org/buy/201019901-007

Gan, Q., \& Yu, Y. (2015). Restaurant ratings: Industry standards and word of mouth - Multi-dimensional text mining and sentiment analysis. In Proceedings of the Annual Hawaii International Conference on Systems Science. Kauai, HI, pp. 1332-1340, doi: 10.1109/HICSS.2015.163.

Goerzen A., Asmussen C.G., Nielsen B.B. (2014) Global Cities and Multinational Enterprise Location Strategy. In: Cantwell J. (eds) Location of International Business Activities. Palgrave Macmillan, London. https:/doi. org/10.1057/9781137472311_6

Hakim, A., \& Hadipapo, A. (2015). Peran Kepemimpinan dan Budaya Organisasi Terhadap Kinerja Sumber Daya Manusia Di Wawotobi, EKOBIS 16, (1), $1-11$.

Halbesleben, J. R. B., \& Wheeler, A. R. (2008). The relative roles of engagement and engagement in predicting job performance and intention to leave. Work and Stress. 22, (3), 242-256, https://doi. org/10.1080/02678370802383962

Hanaysha, J., \& Tahir, P. R. (2016). Researching the Effect of Employee Empowerment, Teamwork, and Employee Training on Job Satisfaction. Procedia - Social and Behavioral Sciences, 219, 272-282. https://doi.org/10.1016/j.sbspro.2016.05.016

Handayani, S., Fariyanti A, dan Nurmalina R. (2016). Swasembada Daging Sapi Analisis Simulasi Ramalan Swasembada Daging Sapi di Indonesia, Sosiohumaniora, 18, (1), 61-70.

Herawati,J.,\&Prayekti,P.(2017).PengaruhKepemimpinan Etis Dan Komitmen Organisasional Terhadap Kinerja Karyawan Koperasi Batik Di Jogjakarta. Sosiohumaniora: Scientific Journal of Social Sciences and Humanities, 1, (1), 36-50. https:// doi.org/10.30738/sosio.vli1.516

Koubova, V., \& Buchko, A. A. (2013). Work-life balance. Management Research Review, 36, (7), 700-719. https:/doi.org/10.1108/MRR-05-2012-0115

Kurtessis, J. N., Eisenberger, R., Ford, M. T., Buffardi, L. C., Stewart, K. A., \& Adis, C. S. (2017). Perceived organizational support: A meta-analytic evaluation of organizational support theory. Journal of management, 43, (6), 1854-1884 
Limakrisna, N., Noor, Z. Z., \& Ali, H. (2016). Employee performance model: Empirical study on civil servants in the West Java Provincial Government. International Journal of Economic Research. (IJER), 13, (3), 707-719

Masakure, O. (2016). Effect of employee loyalty on wages. Journal of Economic Psychology, 56, 274298. https://doi.org/10.1016/j.joep.2016.08.003

Matanda, T., \& Ewing, M. T. (2012). Global brand strategy development process and regional implementation. International Marketing Research Journal. 29, (1), 5-12. https://doi.org/10.1016/j. ijresmar.2011.11.002

Mathew, R. V., \& Panchanatham, N. 2016. An exploratory study of the development of women entrepreneurs: the case of India. Journal of Marketing and Entrepreneurship Research, 18, (2): 232-247.,

Singh, G. K., \& Kposowa, A. J. 2004. Occupational attainment of Asian and white Indians in the United States: gender differences and births across class strata. Overview of Applied Behavioral Science, 4, (2): 137-175.,

Morgan, T.R., Richey Jr, R.G., \& Autry, C.W. (2016). Develop reverse logistics competence. International Journal of Physical Distribution \& Logistics Management, 46, (3), 293-315. https:// doi.org/10.1108/IJPDLM-05-2014-0124

Noor, Z. Z., \& Limakrisna, N. (2019). Workload and competency models, as well as employee performance. Test Engineering and Management. $81,(1), 4322-4330$

Platis, C., Reklitis, P., \& Zimeras, S. (2015). Relationship between Job Satisfaction and Job Performance in Health Services. Procedia - Social and Behavioral Sciences 175, 480-487. https://doi.org/10.1016/j. sbspro.2015.01.1226

Priatna, D. K., \& Roswinna, W. (2019). The influence of leadership motivation and employee performance at Bank Rakyat Indonesia Subang Branch Office. Test Engineering and Management.

Sagita, A. A., Susilo, H., \& Cahyo, M. (2018). Pengaruh Budaya Organisasi Terhadap Kinerja Karyawan Dengan Motivasi Kerja Sebagai Variabel Mediator
(Studi Pada Pt Astra Internasional, Tbk-Toyota (Auto2000) Cabang Sutoyo Malang, Jurnal Administrasi Bisnis (JAB), 57, (1), 73-82.

Siahaan, E., Gultom, P., \& Lumbanraja, P. (2016). Improved employee banking performance based on increased competence and job placement through career development (case study in Indonesia). International Business Management, 10, (3), 255261. https://doi.org/10.3923/ibm.2016.255.261

Singh, J. K. (2013). Employee and Its Job Satisfaction Study. Employee Job Satisfaction Studies and Its, 1 (4), 105-111.

Siswantini, W.,. T., Ayuni, D., \& Mulyana, A. (2014). The Impact Of Employee Motivation On Service Quality And Community Satisfaction Towards Quality Of Public Service In South Tangerang District. Journal of Management and Business. 13, (2), 262-277. https://doi.org/10.24123/jmb. v13i2.250

Sukirno, D. S., \& Siengthai, S. (2011). Does participatory decision making affect the performance of lecturers in tertiary institutions?. International Journal of Educational Management, 25, (5), 494508. https://doi.org/10.1108/09513541111146387

Sutanto, E. M., \& Kurniawan, M. (2016). The impact of recruitment, employee retention and work relations on employee performance in the batik industry in Solo, Indonesia. International Journal of Business and Society, 17, (2), 375-390.

Tuma, J. M., \& Pratt, J. M. (1982). Clinical child psychology practice and training: A survey, Journal of Clinical Child Psychology, 11, (1), 2734, DOI: 10.1080/15374418209533058

Shanker, S. (2003). Philosophy of Meaning, Knowledge and Value in the Twentieth Century. London, United Kingdom: Routledge History of Philosophy Volume 10

Zagenczyk, T. J., Scott, K. D., Gibney, R., Murrell, A. J., \& Thatcher, J. B. (2010). Perceived social influence and organizational support: Social network analysis. Organizational Behavior and Human Decision Processes, 111 (2), 127-138. https://doi. org/10.1016/j.obhdp.2009.11.004 